\title{
Article \\ Co-Exposure with an Invasive Seaweed Exudate Increases Toxicity of Polyamide Microplastics in the Marine Mussel Mytilus galloprovincialis
}

\author{
Filipa G. Rodrigues ${ }^{1} \mathbb{D}$, Hugo C. Vieira ${ }^{2} \mathbb{D}$, Diana Campos ${ }^{2}{ }^{*}$, Sílvia F. S. Pires ${ }^{2} \mathbb{D}$, Andreia C. M. Rodrigues ${ }^{2} \mathbb{D}$, \\ Ana L. P. Silva ${ }^{2}\left(\mathbb{D}\right.$, Amadeu M. V. M. Soares ${ }^{2} \mathbb{D}$, Jacinta M. M. Oliveira ${ }^{2} \mathbb{D}$ and Maria D. Bordalo ${ }^{2} \mathbb{D}$ \\ 1 Department of Biology, University of Aveiro, 3810-193 Aveiro, Portugal; filipagrodrigues@ua.pt \\ 2 CESAM - Centre for Environmental and Marine Studies, Department of Biology, University of Aveiro, \\ 3810-193 Aveiro, Portugal; hugovieira@ua.pt (H.C.V.); silviapires1@ua.pt (S.F.S.P.); \\ rodrigues.a@ua.pt (A.C.M.R.); ana.luisa.silva@ua.pt (A.L.P.S.); asoares@ua.pt (A.M.V.M.S.); \\ jacintaoliveira@ua.pt (J.M.M.O.); maria.bordalo@ua.pt (M.D.B.) \\ * Correspondence: diana.campos@ua.pt
}

check for updates

Citation: Rodrigues, F.G.; Vieira, H.C.; Campos, D.; Pires, S.F.S.; Rodrigues, A.C.M.; Silva, A.L.P.; Soares, A.M.V.M.; Oliveira, J.M.M.; Bordalo, M.D. Co-Exposure with an Invasive Seaweed Exudate Increases Toxicity of Polyamide Microplastics in the Marine Mussel Mytilus galloprovincialis. Toxics 2022, 10, 43. https://doi.org/10.3390/ toxics10020043

Academic Editor: Víctor Manuel León

Received: 15 December 2021

Accepted: 14 January 2022

Published: 18 January 2022

Publisher's Note: MDPI stays neutral with regard to jurisdictional claims in published maps and institutional affiliations.

Copyright: (C) 2022 by the authors. Licensee MDPI, Basel, Switzerland. This article is an open access article distributed under the terms and conditions of the Creative Commons Attribution (CC BY) license (https:// creativecommons.org/licenses/by/ $4.0 /)$.

\begin{abstract}
Plastic pollution and invasive species are recognised as pervasive threats to marine biodiversity. However, despite the extensive on-going research on microplastics' effects in the biota, knowledge on their combination with additional stressors is still limited. This study investigates the effects of polyamide microplastics (PA-MPs, $1 \mathrm{mg} / \mathrm{L}$ ), alone and in combination with the toxic exudate from the invasive red seaweed Asparagopsis armata (2\%), after a $96 \mathrm{~h}$ exposure, in the mussel Mytilus galloprovincialis. Biochemical responses associated with oxidative stress and damage, neurotoxicity, and energy metabolism were evaluated in different tissues (gills, digestive gland, and muscle). Byssus production and PA-MP accumulation were also assessed. Results demonstrated that PA-MPs accumulated the most in the digestive gland of mussels under PA-MP and exudate co-exposure. Furthermore, the combination of stressors also resulted in oxidative damage at the protein level in the gills as well as in a significant reduction in byssus production. Metabolic capacity increased in both PA-MP treatments, consequently affecting the energy balance in mussels under combined stress. Overall, results show a potential increase of PA-MPs toxicity in the presence of A. armata exudate, highlighting the importance of assessing the impact of microplastics in realistic scenarios, specifically in combination with co-occurring stressors, such as invasive species.
\end{abstract}

Keywords: invasive macroalgae; bivalves; marine debris; oxidative stress; energy balance; byssus production

\section{Introduction}

Marine environments represent an important life support system and one of the most complex ecosystems [1]. Nevertheless, biodiversity and marine resources are increasingly endangered due to pollution and other anthropogenic issues associated with the fast pace of human population growth and the development of the economy. The introduction of non-native marine species, overfishing, global climate change, and habitat destruction and modification are key pressure points, especially in coastal areas [2].

Global plastic production has increased dramatically in recent years, reaching almost 370 million tonnes in 2019 [3], raising growing scientific and societal concerns. In particular, microplastics (MPs: $<5 \mathrm{~mm}$ in size) are an emerging environmental issue that accounts for the major percentage of plastic litter, having been detected in many environmental matrices [4]. These polymers are introduced in marine ecosystems through multiple pathways, such as direct disposal, airborne dispersal, terrestrial runoff, and riverine flow [5,6]. MP levels are expected to range between $<0.0001$ and $1.89 \mathrm{mg} / \mathrm{L}$ in the marine environment [7]. However, as these particles undergo continuous fragmentation, and considering that most 
surveys do not detect particles $<300 \mu \mathrm{m}$, the concentrations found in the environment are probably underestimated [8]. Several studies have observed that MPs are widely available to the marine food web [9], as they are very similar in size to various organisms in the planktonic and benthic communities [9]. The intake of MPs can occur via gills or through direct consumption (i.e., particle ingestion) or indirectly (i.e., via trophic chains) $[6,10]$. Therefore, the bioavailability of MPs to marine biota is the primary environmental risk associated with this pollutant $[9,11]$. In this regard, filter-feeding marine organisms, such as bivalves, are probably among the most impacted groups, since they can involuntarily ingest these synthetic materials along with the natural food items while feeding by constantly filtrating substantial volumes of seawater [12]. Once ingested, small-sized MPs can be taken up into the cells by endocytosis and are accumulated or translocated to different tissues in the organisms [13-15]. MP intake may, therefore, lead to histological alterations, inflammatory reactions, and ecotoxicological responses at cellular, molecular, and biochemical levels, as they are responsible for detrimental modulations of biological functions, such as reproduction, growth, survival, and feeding $[9,16]$.

There are different types of plastic polymers and one of the most common groups includes polyamides (PA) [17], which are important engineering plastics often used in domestic and automotive industries [18] due to their high durability and resistance. Furthermore, these particles may be released from fishing gear and aquaculture facilities [6,19], and are frequently detected in coastal waters, including biotic [20,21], water [22], and sediment compartments [23]. PA particles can be found from the intertidal to the subtidal environments [24], as they have a density similar to seawater, allowing them to remain suspended in the water-column [10], remaining available as a "food item" for filter-feeding marine organisms.

The proliferation of invasive species has also been a major cause of concern in marine ecosystems, posing a threat to biodiversity and potentially leading to severe alterations in the functioning and structure of the ecosystem. In particular, marine macroalgae constitute the main component of introduced biota, with a current global estimate varying from 163 to over 300 species [25]. The northeast Atlantic and the Mediterranean coasts support the largest number of macroalgae introductions [26], with the main human-mediated vectors responsible for their transport being maritime traffic (e.g., hull fouling, ballast waters), aquaculture, and aquarium trade [27]. Once non-native macroalgae spread beyond their natural distribution through human activities and become successfully established, they are defined as invasive [28], competing with native species, and potentially leading to their displacement. Invasive species may also modify habitats and their structure, promoting biodiversity loss, and creating cascading effects or changes in the food chain [29], which may cause significant ecological and economic damages [30]. Asparagopsis armata Harvey, 1855 is a red seaweed native to Southern Australia and New Zealand [31], first described in the Atlantic and Mediterranean coasts in the 1920s [32], as it is widely distributed from the British Isles to Senegal [33,34], including the Azores Islands and mainland Portugal [35,36]. It is globally known for strong invasive behaviour due to its type of life cycle (leading to fast and vast propagation mainly due to its free-living stage) and lack of predators in the invaded habitat [37]. Exudation of secondary metabolites, including halogenated compounds such as haloforms, haloketones, and haloacids, constitutes a chemical defence mechanism that is a key aspect for A. armata invasiveness by becoming unpalatable for predators $[38,39]$. Thus, this seaweed has been considered an important source of bioactive metabolites with antibacterial and antifungal properties [40], and some were also found to have mutagenic and cytotoxic effects [41]. This red macroalga is mainly found from the low intertidal to the shallow subtidal zone [42], often attached to the substrate or drifting, and tend to concentrate in rock pools during low tide [43]. In this type of environment, such chemical compounds, once exuded into the water, may be potentially toxic and pose a threat to native biota [43]. Some previous studies have already devoted attention to the impact of $A$. armata exudate on the surrounding biota. For instance, exposure to A. armata halogenated metabolites caused physiological impairment on the crustacean Palaemon elegans, the gastropod Gibbula umbilicalis, and the 
mussel Mytilus galloprovincialis [43-45]. Low exudate concentrations were also found to reduce feeding activity of G. umbilicalis and M. galloprovincialis as well as the byssal production and strength of M. galloprovincialis [44,45]. Moreover, a tendency of an increasingly toxic action of the exudate was observed in M. galloprovincialis under a warming temperature scenario [46].

Mussels are abundant, widespread bivalves, and key players within marine trophic chains, being frequently selected as sentinel organisms and used in ecotoxicological studies for monitoring coastal environments as representative of low-trophic level organisms [47]. The mussel M. galloprovincialis is considered an ecologically important organism in coastal waters and is frequently used as a bioindicator of MP pollution in marine environments [4]. The sedentary and suspension filter-feeding behaviours of this mussel species translates in a great capacity to uptake and accumulate many contaminants, consequently providing a specific response that reflects the effects of different perturbations [48]. Furthermore, this species represents an important link between benthic and pelagic ecosystems [4] and forms dense monolayered and multi-layered beds attached to the hard substrate along intertidal rocky shores providing habitat structures and shelter to various organisms, increasing habitat complexity and enhancing the biodiversity [49]. M. galloprovincialis also has a high socio-economic value, representing an important food resource globally consumed by human populations due to its nutritional relevance, hence representing one of the most harvested and produced species, particularly in Portugal [50].

Considerable investigations have been carried out on the effect of different MPs in the mussel, M. galloprovincialis [4,12,14,48,51], but none studied the consequence of this exposure in co-occurrence with the exuded compounds from an invasive seaweed. The presence of different stressors in the environment may lead to complex interactions and scenarios that need to be taken into account when evaluating their impact in order to identify realistic scenarios of exposure. Furthermore, despite being a commonly found polymer in coastal waters [20-22], there is a knowledge gap of the effect of PA-MPs in marine organisms. In this sense, the present study aimed to evaluate the consequences of PA-MP exposure in the mussel $M$. galloprovincialis and assess the influence of $A$. armata exudate on the impacts caused by this polymer. Physiological responses, including byssal thread production, oxidative damage, antioxidant defences, enzymatic activity for cholinergic neurotransmission, energy production, and metabolism, were measured.

\section{Materials and Methods}

\subsection{Asparagopsis armata Sampling and Exudate Production}

The red macroalga $A$. armata (gametophyte phase) was collected by hand through free diving in the subtidal zone at the Terceira Island in Azores (Portugal) $\left(38^{\circ} 38^{\prime} 59.2^{\prime \prime} \mathrm{N}\right.$, $\left.27^{\circ} 13^{\prime} 16.4^{\prime \prime} \mathrm{W}\right)$. After collecting, the macroalgae were kept in aerated seawater tanks until the next day and packed in sealed containers to be transported to the laboratory in Aveiro (Portugal). Upon arrival, A. armata was immediately cleared from any perceptible associated fauna and debris. Afterwards, they were allocated to a tank with artificial seawater (marine RedSea ${ }^{\circledR}$ Salt premium grade) in a 1:10 proportion (salinity: $35 \pm 1, \mathrm{pH}: 8.0 \pm 0.1$, temperature: $20.0 \pm 0.5^{\circ} \mathrm{C}$ ) in the dark and with no aeration for $24 \mathrm{~h}$ to produce the exudate, adapted from [45]. Algae were then removed from the tank and the resulting media (considered as the stock solution, representing $100 \%$ of exudate) was preserved at $-20{ }^{\circ} \mathrm{C}$. When needed, the exudate was slowly defrosted in the dark at $4{ }^{\circ} \mathrm{C}$, and used at a $2 \%$ concentration, chosen according to previous sublethal toxicity test results [45].

\subsection{Mytilus galloprovincialis Sampling and Acclimation}

In December 2020, adult specimens of M. galloprovincialis (4.2 $\pm 0.1 \mathrm{~cm}$ shell length) were harvested by hand, on the intertidal rocky shore of the Barra of Aveiro in Portugal $\left(40^{\circ} 38^{\prime} 38.8^{\prime \prime} \mathrm{N}, 8^{\circ} 44^{\prime} 44.6^{\prime \prime} \mathrm{W}\right)$, during low tide. Mussels were measured with a pachymeter in the field and then transported to the laboratory, where the shell surface was gently scraped to remove algae, encrusting organisms, and debris. Afterwards, M. galloprovincialis individuals were allowed to depurate and acclimate during seven days in glass aquariums that contained 
aerated artificial seawater (salinity: $30.0 \pm 0.5$; temperature: $19.0 \pm 0.5^{\circ} \mathrm{C}$; $\mathrm{pH}: 8.0 \pm 0.1$; dissolved oxygen: $8.0 \pm 0.5 \mathrm{mg} / \mathrm{L}$; oxygen saturation: $>80 \%$, measured with WTW portable meters, Weilheim, Germany) in a recirculating aquatic system (a flow-through system ensured continuous seawater renewal), with a $14 \mathrm{~h}$ light:10 h dark photoperiod.

\subsection{Microplastic Preparation}

Polyamide microplastics (PA-MP, mean size: 30-50 $\mu \mathrm{m}$, irregularly shaped, density: $1.14 \mathrm{~g} / \mathrm{cm}^{3}$; CAS 32131-17-2, Figure S1) were generously provided by a company that chose to remain anonymous. A stock solution (100 mg PA-MP/L) was prepared in artificial seawater (salinity: 30 ; RedSea ${ }^{\circledR}$ Salt premium grade mixed with reverse osmosis water) previously filtered $(0.45 \mu \mathrm{m}$ pore size). This PA-MP solution was allowed to equilibrate for $96 \mathrm{~h}$ at $50 \mathrm{rpm}$ at room temperature in the dark. A solution containing only artificial seawater to be used in the treatments without PA-MPs was prepared and left to shake in the same conditions. The final concentration was achieved by adding $5 \mathrm{~mL}$ of the stock solution to the test vials containing $495 \mathrm{~mL}$ of seawater, resulting in a final concentration of $1 \mathrm{mg} / \mathrm{L}$, which fits within realistic environmental MP concentrations [7]. In the treatments without PA-MP, $5 \mathrm{~mL}$ of the aged artificial seawater were also added.

\subsection{Experimental Setup}

After acclimation, 48 mussels were exposed for $96 \mathrm{~h}$ to the following treatments: (i) control (artificial seawater only); (ii) A. armata exudate ( $2 \%$ concentration); (iii) PA-MPs (1 mg/L); and (iv) A. armata exudate ( $2 \%$ ) and PA-MPs ( $1 \mathrm{mg} / \mathrm{L})$, simultaneously. The $96 \mathrm{~h}$ exposure was selected in accordance with American Society for Testing and Materials E729-96 [52]. For each treatment (control; exudate exposure; PA-MP exposure; and exudate and PA-MP exposure), 12 replicates were used with 1 mussel placed individually in $1 \mathrm{~L}$ glass flasks containing $500 \mathrm{~mL}$ of aerated test medium (static exposure). Seven replicates were used for the biomarkers' analysis, and the remaining five replicates were used for PA-MP quantification. The physical-chemical test parameters were maintained at salinity$30.5 \pm 0.3$, temperature $-18.0 \pm 0.3^{\circ} \mathrm{C}, \mathrm{pH}-8.0 \pm 0.2$, dissolved oxygen $-8.0 \pm 0.5 \mathrm{mg} / \mathrm{L}$, oxygen saturation $\longrightarrow 83 \%$, and a $14 \mathrm{~h}$ light: $10 \mathrm{~h}$ dark photoperiod was used. After the $96 \mathrm{~h}$ of exposure, the soft tissues of each mussel were removed using a scalpel and tweezers. Tissue samples (gills, muscles, and digestive gland) for the biomarkers analysis were individually stored and weighed in microcentrifuge tubes, frozen in liquid nitrogen and subsequently stored at $-80^{\circ} \mathrm{C}$ prior to further analysis. Samples for the PA-MP quantification (gills and digestive gland) were kept in small glass flasks (for the microplastic quantification) and preserved at $-20^{\circ} \mathrm{C}$.

\subsection{Digestion of Mussel Tissues and Microplastic Quantification}

The digestion and filtration procedures were adapted from the method developed by Prata et al. [53].

A $10 \%$ potassium hydroxide $(\mathrm{KOH})(w / v \geq 85 \%$, Fisher Scientific, Loughborough, UK, CAS 1310-58-3) solution (100 g of KOH pellets dissolved in $1000 \mathrm{~mL}$ Milli-Q ultra-pure water) was freshly prepared and used to digest the mussels' tissues. Ten $\mathrm{mL}$ of the $\mathrm{KOH}$ solution were added to each glass flask containing the samples, covered with aluminium foil, and incubated at $50{ }^{\circ} \mathrm{C}$ for $48 \mathrm{~h}$. After the incubation period was over, the filtration of the samples followed.

The samples were heated to boiling just before being filtered to improve the solubility of fats and soaps and, consequently, the filtration rates. Then, samples were vacuumed filtered onto glass microfiber filters ( $47 \mathrm{~mm} \varnothing ; 1.2 \mu \mathrm{m}$ pore size, Prat Dumas, Couze-StFront, France), washed with $50 \mathrm{~mL}$ of boiling Milli-Q ultra-pure water, followed by the addition of $10 \mathrm{~mL}$ of acetone (99.5+\%, Fisher Scientific, Loughborough, UK, CAS 67-64-1). Samples were then incubated for $10 \mathrm{~min}$ and washed with ultra-pure water.

To assure quality control during testing, the glassware was acid-washed and rinsed with Milli-Q ultra-pure water; procedural blanks (1 per every 10 samples) were prepared 
with the $\mathrm{KOH}$ solution and received the same treatment as the other samples; for digestion, tissue samples were prepared and handled under a laminar flow chamber.

After drying, each glass fibre filter of each sample (including blanks) was observed under a stereomicroscope (Zeiss, Stemi 2000, Jena, Germany), and the number of PA-MP particles was visually counted. All fibres were discarded from the analysis. In case of any doubt, PA-MPs were confirmed by applying the method of hot needle [54]. The number of PA-MPs is presented as the number of counted particles/g tissue/organism.

\subsection{Biomarker Analysis}

\subsubsection{Sample Preparation}

Samples of M. galloprovincialis tissues (gills, muscles, and digestive glands) were individually homogenised on ice through sonication (10\% pulse mode, 250 Sonifier, Branson Ultrasonics, Danbury, CT, USA) using $1500 \mu \mathrm{L} 0.1 \mathrm{M} \mathrm{K-phosphate} \mathrm{buffer,} \mathrm{pH-7.4.} \mathrm{Muscle}$ samples to be analysed for energy metabolism were homogenised using the same procedure in $1500 \mu \mathrm{L}$ ultra-pure water.

After homogenisation, one aliquot from each gill, digestive, and muscle replicate was stored with $4 \%$ butylated hydroxytoluene (BHT) in methanol to evaluate the lipid peroxidation (LPO). Aliquots for protein carbonylation (PC) determination were also stored. The remaining homogenate of gills and digestive samples was centrifuged for $15 \mathrm{~min}$ at $10,000 \mathrm{~g}\left(4^{\circ} \mathrm{C}\right)$, and the obtained post-mitochondrial supernatant (PMS) was divided into microtubes and kept in $-80^{\circ} \mathrm{C}$ for posterior analysis of catalase (CAT), glutathione S-transferase (GST), and acetylcholinesterase (AChE) activities, and total glutathione (tGSH) content. The PMS from the muscle homogenate was used for determining AChE activity in this tissue.

Aliquots of muscle homogenates were also stored for the analysis of lactate dehydrogenase (LDH) activity, proteins, lipids, and sugars contents, and electron transport system (ETS) activity.

Biomarkers determinations were done in micro-assays set up in 96-well flat bottom plates and read spectrophotometrically (Microplate reader MultiSkan Spectrum (Thermo Fisher Scientific, Waltham, MA, USA).

\subsubsection{Oxidative Stress and Neurophysiological Biomarkers}

The protein concentration of PMS was determined according to the Bradford method [55], using bovine-globulin as a standard. The Ellman's method [56], adapted to the microplate [57], was applied to measure acetylcholinesterase (AChE) activity, using acetylthiocholine as substrate and following the absorbance increase at $412 \mathrm{~nm}$. Catalase (CAT) activity was measured in the PMS by following the decomposition of the substrate hydrogen peroxide $\left(\mathrm{H}_{2} \mathrm{O}_{2}\right)$ at $240 \mathrm{~nm}$ [58]. Glutathione-S-transferase (GST) activity was measured in PMS after the conjugation of reduced glutathione (GSH) with 1-chloro-2,4-dinitrobenzene (CDNB) at $340 \mathrm{~nm}$ [59]. The total glutathione ( $\mathrm{tGSH}$ ) content was determined in the PMS fraction using the recycling reaction of GSH with 5,50-dithiobis-(2-nitrobenzoic acid) (DTNB) in the presence of glutathione reductase (GR) excess at $412 \mathrm{~nm}$ [60-62]. To determine endogenous lipid peroxidation (LPO) thiobarbituric acid-reactive substances (TBARS) were measured at $535 \mathrm{~nm}$ [63]. Protein carbonylation (PC) was quantified at $450 \mathrm{~nm}$ based in the reaction of 2,4-dinitrophenylhydrazine (DNPH) with carbonyl groups, according to the DNPH alkaline method [64]. Lactate dehydrogenase (LDH) activity was determined by following the NADH oxidation caused by pyruvate consumption, as it leads to the decrease of absorbance at $340 \mathrm{~nm}$ [65], adapted to the microplate [66].

\subsubsection{Cellular Energy Allocation (CEA)}

CEA value is obtained from the ratio between Ea, the energy available (the sum of proteins, lipids, and sugar contents), and Ec, which is aerobic energy production (estimation of ETS activity). The CEA and ETS activity were determined based on the methods described by De Coen and Janssen [67], slightly modified for the microplate [68]. 
Total lipid content in muscle tissue was determined by adding chloroform, methanol, and ultra-pure water in a 2:2:1 proportion. In the organic phase of each sample, sulfuric acid $\left(\mathrm{H}_{2} \mathrm{SO}_{4}\right)$ was added, followed by an incubation period of $15 \mathrm{~min}$ at $200{ }^{\circ} \mathrm{C}$, and the absorbance was measured at $375 \mathrm{~nm}$ using tripalmitin as a lipid standard. To determine the carbohydrate and protein contents, $15 \%$ thiobarbituric acid (TCA) was added to $300 \mu \mathrm{L}$ of homogenate and incubated for $10 \mathrm{~min}$ at $-20{ }^{\circ} \mathrm{C}$. Carbohydrate quantification was performed in the supernatant by adding $5 \%$ phenol and $\mathrm{H}_{2} \mathrm{SO}_{4}$ to the samples, and the absorbance was read at $492 \mathrm{~nm}$, using glucose as a standard. For total protein content quantification, the remaining pellet was resuspended with $1 \mathrm{M} \mathrm{NaOH}$ (incubated for $30 \mathrm{~min}$ at $60^{\circ} \mathrm{C}$ ) and then neutralized with $1.67 \mathrm{HCl}$. Total protein content quantification followed the Bradford's method [55], using bovine serum albumin as a standard and measuring absorbance at $520 \mathrm{~nm}$. Proteins, lipids, and sugar fractions were converted into energetic equivalent values using the corresponding energy of combustion: $24,000 \mathrm{~mJ} / \mathrm{g}, 39,500 \mathrm{~mJ} / \mathrm{g}$, and $17,500 \mathrm{~mJ} / \mathrm{g}$, respectively [69].

Electron transport system (ETS) activity was evaluated using the INT (Iodonitrotetrazolium chloride) reduction assay by measuring the rate of INT reduction in the presence of the non-ionic detergent Triton X-100, at $490 \mathrm{~nm}$. The stoichiometric relationship in which for $2 \mu \mathrm{mol}$ of formazan formed, $1 \mu \mathrm{mol}$ of oxygen is consumed was applied to calculate the cellular oxygen consumption rate. The final Ec value was converted into an energy equivalent using the specific oxyenthalpic equivalent for an average lipid, protein, and carbohydrate mixture of $480 \mathrm{~kJ} / \mathrm{mol} \mathrm{O}_{2}$ [69].

\subsection{Byssal Thread Production}

The quantity of produced byssal threads was assessed as a physiological biomarker. Once the $96 \mathrm{~h}$ exposure period for the different treatments ( $0 \%$ exudate; $2 \%$ exudate; PAMPs; and 2\% exudate and PA-MPs) ended, the number of functional byssus produced by each M. galloprovincialis individual was counted, according to Coelho et al. [45]. For this evaluation, all 12 replicates were used.

\subsection{Statistical Analysis}

The statistical analysis of data and graphical representations of results was performed using IBM SPSS Statistics 27 and GraphPad Prism 9 for Windows. Data normality and homoscedasticity were assessed on the residuals, using the Shapiro-Wilk Test $(p>0.05)$ and the Levene's Test $(p>0.05)$, respectively. For variables not showing a normal distribution or homoscedasticity, data were square root (CAT, GST, LPO, AChE, tGSH, AChE, LDH, and $\mathrm{AChE}$ in the muscle) or log-transformed (lipid content, ETS activity, Ea, and PA-MP quantification in the digestive gland).

Parametric t-tests were performed to evaluate differences in the number of PA-MP particles per tissue between treatments exposed to PA-MP. One-way analysis of variance (ANOVA) with a post hoc Dunnet's test was used to investigate treatment-dependent effects on byssus production. Effects on biochemical responses among A. armata exudate, PA-MPs and their interactions after exposure were evaluated through two-way ANOVA, using $A$. armata exudate and PA-MPs as factors (IBM SPSS Software, Armonk, NY, USA). The post hoc Šídák's test was used to perform multiple comparisons and identify significant differences between treatments (GraphPad Software, CA, USA). Data were presented as mean value (mean) \pm standard error of mean value (SEM).

\section{Results}

\subsection{Polyamide Microplastics Quantification}

PA-MP particles were found mainly in the digestive gland and, at a lesser amount, in the gills (Table 1). Despite the observed increase in the number of particles between the PA-MP treatment and the combined exposure, this difference was not significant $(p>0.05)$. 
Table 1. Number of polyamide microplastics (PA-MPs) per gram of tissue (gills and digestive gland) in Mytilus galloprovincialis exposed to PA-MPs and PA-MPs together with A. armata exudate. All values are presented mean \pm SEM. ww $=$ wet weight.

\begin{tabular}{ccc}
\hline \multirow{2}{*}{ Tissue } & \multicolumn{2}{c}{ Number of Particles per Gram Tissue (ww) } \\
\cline { 2 - 3 } & PA-MP & PA-MP + Exudate \\
\hline Gills & $6.97 \pm 3.08$ & $11.95 \pm 4.83$ \\
Digestive gland & $35.04 \pm 16.09$ & $62.25 \pm 25.98$ \\
\hline
\end{tabular}

\subsection{Oxidative Stress and Neurophysiological Biomarkers}

In the gills, a significant effect of PA-MPs factor was observed for CAT activity of exposed mussels (Table S1); however, despite the observed tendency to decrease CAT activity, the post hoc test could not discriminate significant differences among the several treatments (Figure 1a). Considering the GST activity (Figure 1b), no significant changes in the presence of $A$. armata exudate, PA-MPs, or even by the interaction between $A$. armata exudate and PA-MPs were observed (Table S1). On the other hand, significant effects were observed in the levels of tGSH in the presence of PA-MPs and in mussels exposed to both stressors, reflected by the significant interaction between $A$. armata exudate and PA-MPs (Table S1). Specifically, there were significant differences within the $2 \%$ exudate concentration $(p<0.05)$; i.e., the tGSH levels exhibited a decrease in the mussels exposed to exudate in the presence of PA-MPs, when compared to the single exposure of $A$. armata exudate (Figure 1c).

Regarding the oxidative damage in the mussel gills, no changes in PC levels were observed in mussels exposed to PA-MPs and A. armata exudate; however, the interaction between these factors significantly affected PC levels (Table S1). Furthermore, PC levels demonstrated a significant difference in mussels exposed to the $2 \%$ exudate concentration $(p<0.05)$, with increased values in the exposure to $A$. armata exudate in the presence of PA-MPs, when compared to the $2 \%$ exudate treatment (Figure 1d). A significant difference within the $1 \mathrm{mg}$ PA-MP/L $(p<0.05)$ was also verified, whereas the exposure to PA-MPs in the presence of $2 \%$ exudate exhibited superior PC levels when compared with the exposure to PA-MPs without exudate (Figure 1d). On the other hand, LPO was not significantly affected by A. armata exudate, PA-MPs, or their interaction (Table S1, Figure 1e). Regarding neurotoxicity, none of the experimental treatments resulted in significant effects $(p>0.05)$ in the AChE activity (Table S1, Figure 1f).

In the digestive gland, no significant effects $(p>0.05)$ of $A$. armata exudate exposure or PA-MPs were observed in CAT activity; however, the interaction of these two factors resulted in a significant alteration $(p<0.05)$ in CAT activity (Table S2). Despite that, the post hoc tests did not detect statistical differences among treatments (Figure 2a). Considering the GST activity and tGSH levels, no significant effects $(p>0.05)$ of $A$. armata exudate exposure, PA-MPs, and their interaction were observed (Table S2, Figure 2b,c)

Considering the oxidative damage in the mussels' digestive gland, no significant alterations $(p>0.05)$ in PC levels were observed when organisms were exposed to A. armata exudate, and no interaction of $A$. armata exudate and PA-MPs was observed either (Table S2). However, the PC levels were significantly affected in mussels exposed to PA-MPs $(p<0.05$, Table S2). The post hoc test revealed significant differences within the $2 \%$ exudate concentration $(p>0.05)$ in the levels of PC. A significant increase of PC levels was verified in mussels exposed to $2 \%$ exudate in the presence of PA-MPs, when compared to the single exposure of A. armata exudate without PA-MPs (Figure 2d). As observed in gills, LPO levels did not exhibit alterations in the digestive gland in none of the treatments ( $p>0.05$, Table S2, Figure 2e). Finally, the exposure to A. armata exudate and PA-MPs did not interfere with the activity of $\mathrm{AChE}$, and there was no interaction between the two tested stressors ( $p>0.05$, Table S2). 

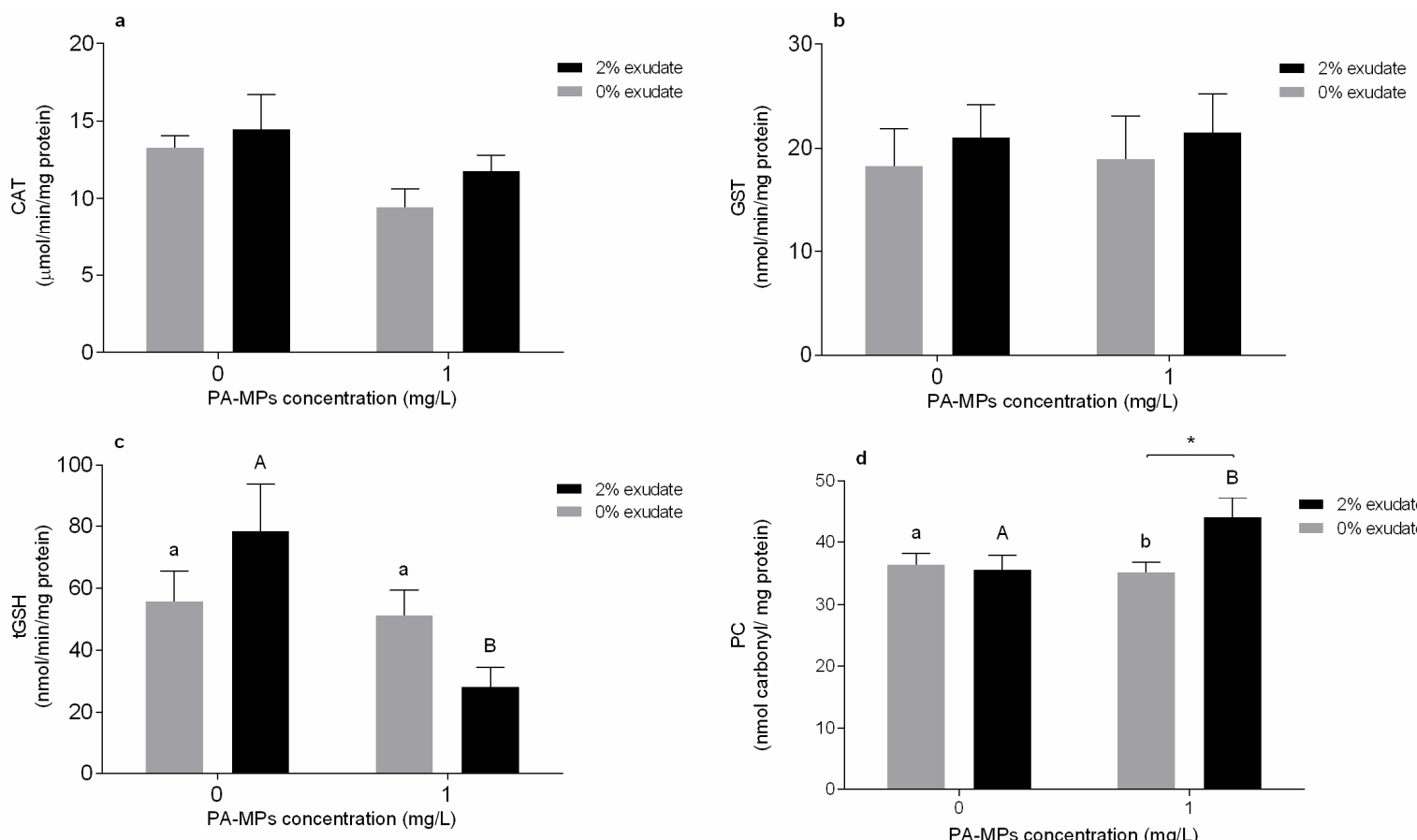

$2 \%$ exudate
$0 \%$ exudate
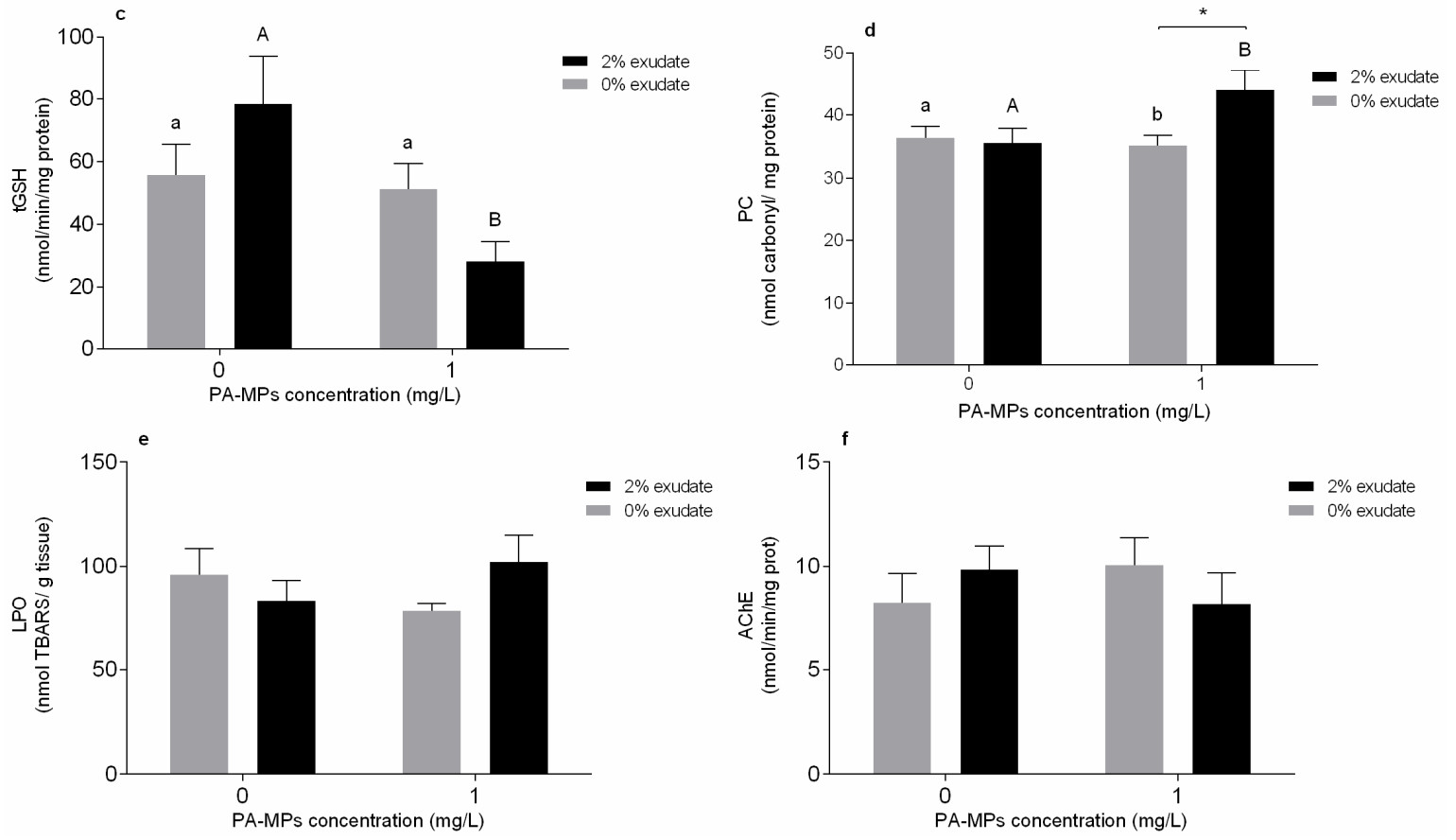

Figure 1. Oxidative stress-related biomarkers of Mytilus galloprovincialis gills after $96 \mathrm{~h}$ of exposure to $A$. armata exudate $(0 \%$ and $2 \%$ ) at different polyamide microplastic (PA-MPs) concentrations (0 and $1 \mathrm{mg} / \mathrm{L})$. (a) Catalase activity (CAT), (b) glutathione-S-transferase activity (GST), (c) total glutathione contents (tGSH), (d) protein carbonylation levels (PC), (e) lipid peroxidation (LPO), and (f) acetylcholinesterase activity (AChE). All values are presented as mean $\pm \mathrm{SEM}$. * denotes a significant difference between the $0 \%$ and $2 \%$ A. armata exudate in the same PA-MPs concentration. The upper-case letters indicate differences in the $0 \%$ exudate treatments and the different lower-case letters represent differences in the $2 \%$ exudate treatments at the different PA-MPs concentrations.

In the muscle, LPO (Figure 3a) and PC (Figure 3b) did not undergo significant alterations $(p>0.05)$ when exposed to exudate, PA-MPs, or their interaction (Table S3). On the other hand, the AChE activity was significantly affected in mussels exposed to $A$. armata exudate $(p<0.05)$ but was not influenced $(p>0.05)$ by the presence of PA-MPs or by the interaction between factors (Table S3). Despite that, no statistical differences among treatments were observed (Figure 3c). 

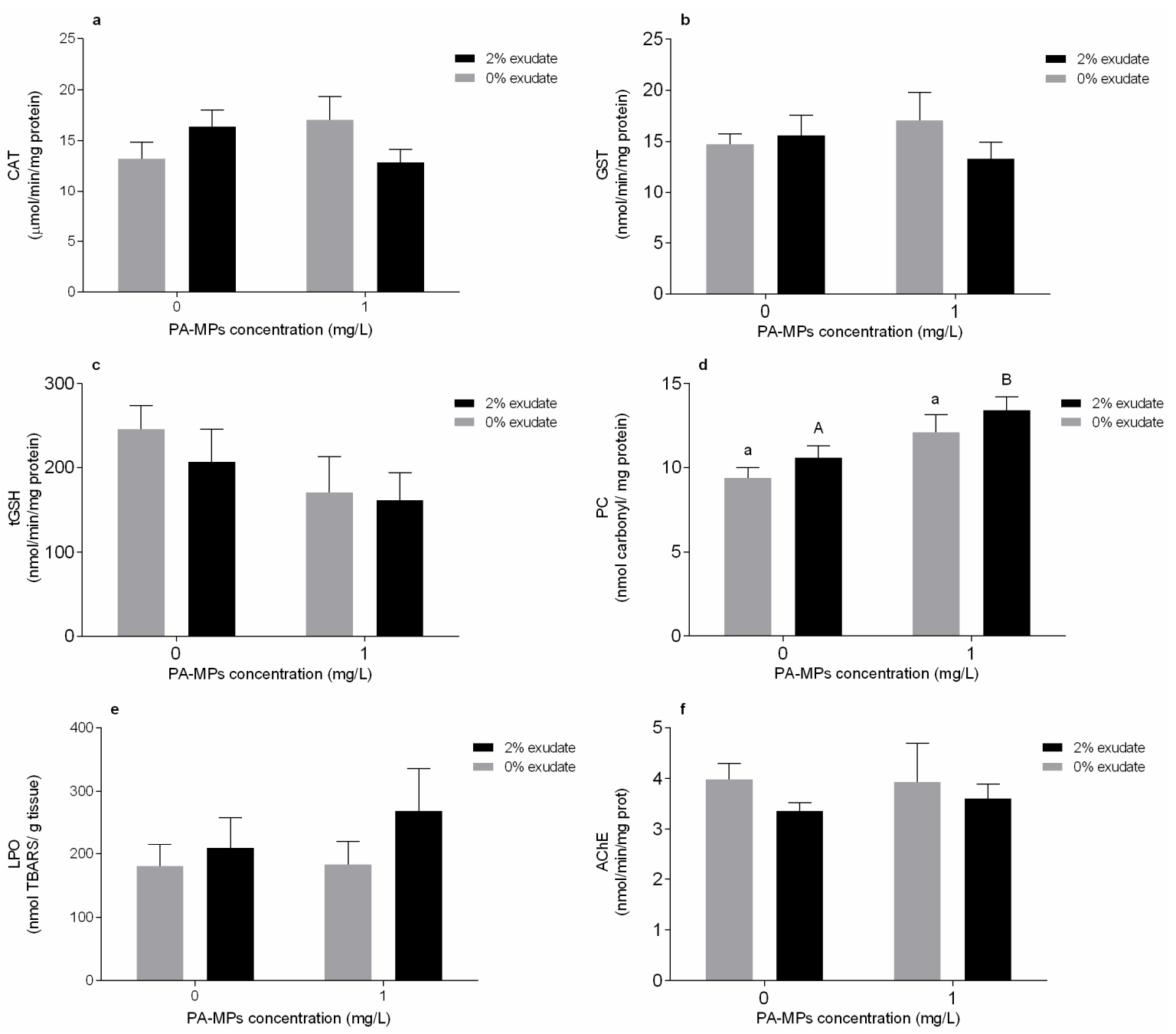

Figure 2. Oxidative stress-related biomarkers of Mytilus galloprovincialis digestive gland after $96 \mathrm{~h}$ of exposure to $A$. armata exudate $(0 \%$ and $2 \%)$ at different polyamide microplastic (PA-MPs) concentrations $(0$ and $1 \mathrm{mg} / \mathrm{L})$. (a) Catalase activity (CAT), (b) glutathione-S-transferase activity (GST), (c) total glutathione contents (tGSH), (d) protein carbonylation levels (PC), (e) lipid peroxidation (LPO), and (f) acetylcholinesterase activity (AChE). All values are presented as mean $\pm \mathrm{SEM}$. The upper-case letters indicate differences in the $0 \%$ exudate treatments, and the different lower-case letters represent differences in the $2 \%$ exudate treatments at the different PA-MPs concentrations.

\subsection{Energy Metabolism Biomarkers}

Considering the energy metabolism in the muscle tissue, the activity of LDH (Figure 4a), lipid levels (Figure 4 b), and protein content (Figure $4 c$ ) were not affected by the presence of $A$. armata exudate or PA-MPs, and there was no interaction between factors $(p>0.05$, Table S3). In addition, the single exposure to the exudate and the PA-MPs had no significant effect $(p>0.05)$. On the other hand, the interaction between $A$. armata exudate and PA-MPs demonstrated a significant impact on the sugar content $(p<0.05$, Table S3). There was an increase in sugar content in individuals exposed to PA-MPs in the presence of $2 \%$ exudate compared to the single exposure to PA-MPs (Figure $4 \mathrm{~d}, p>0.05$ ). There was also a significant increase of sugar levels in mussels exposed to exudate in the presence of PA-MPs, when compared to the treatment with only A. armata exudate (Figure $4 \mathrm{~d}, p<0.05$ ). 

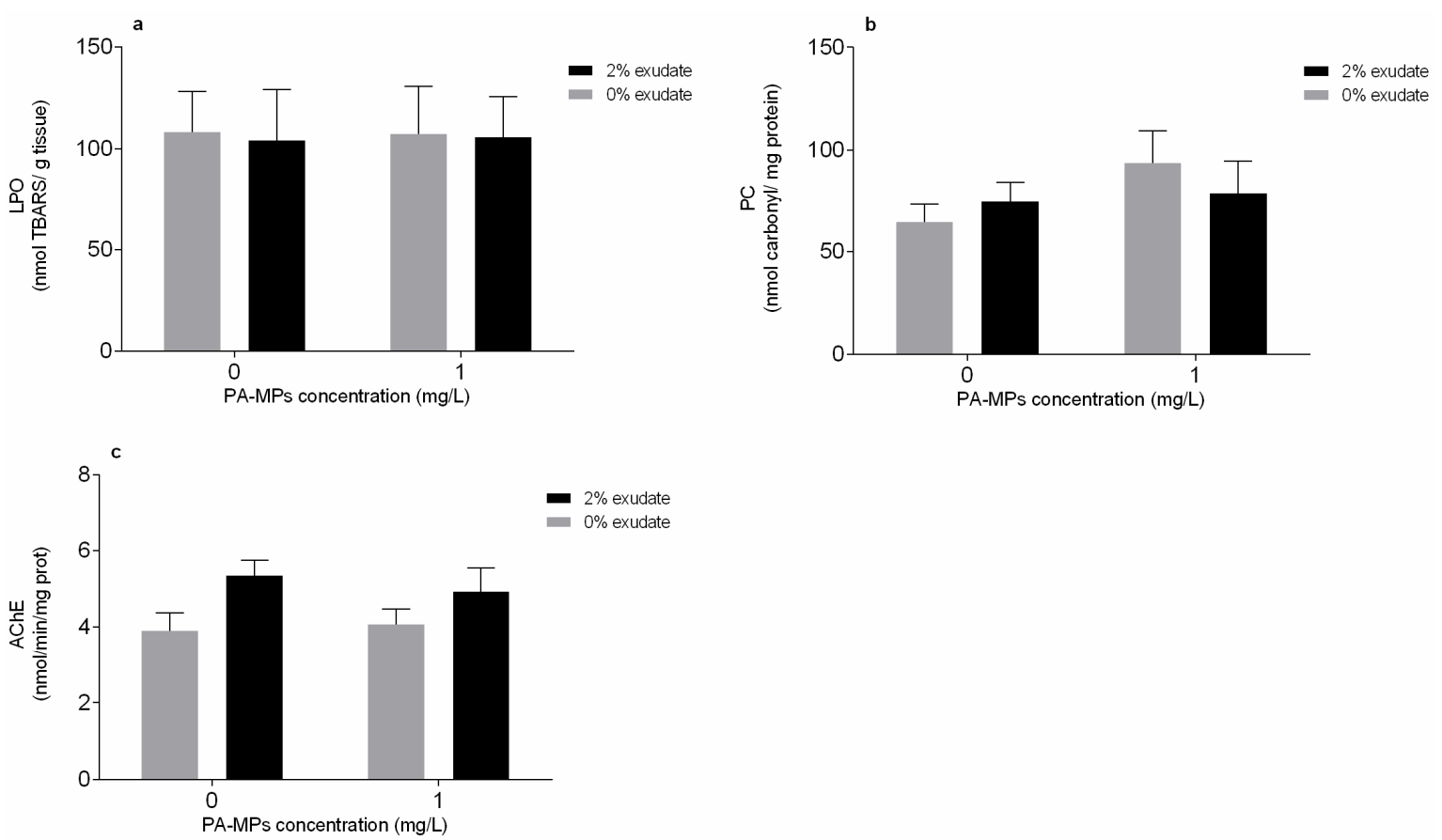

Figure 3. Oxidative stress-related biomarkers of Mytilus galloprovincialis muscles after $96 \mathrm{~h}$ of exposure to A. armata exudate ( $0 \%$ and $2 \%$ ) at different polyamide microplastic (PA-MPs) concentrations (0 and $1 \mathrm{mg} / \mathrm{L})$. (a) Lipid peroxidation (LPO), (b) protein carbonylation levels (PC), and (c) acetylcholinesterase activity (AChE). All values are presented as mean $\pm \mathrm{SEM}$.

Regarding the aerobic metabolic capacity, ETS activity $\left(\mathrm{E}_{\mathrm{c}}\right)$ was impacted in individuals exposed to PA-MPs $(p<0.05)$ but was not affected by the presence of $A$. armata exudate or the interaction of factors $(p>0.05$, Table S3). These alterations were not reflected in the overall energy available $\left(\mathrm{E}_{\mathrm{a}}\right)$ in the presence of $A$. armata exudate $(p>0.05)$, PA-MPs $(p>0.05)$ and there was also no interaction $(p>0.05)$.

CEA was affected in mussels exposed to the PA-MPs treatment $(p<0.05)$, and there were no modifications in individuals exposed to exudate or both factors ( $p>0.05$, Table S3). There was a significant difference in the $2 \%$ exudate concentration $(p<0.05)$, i.e., a decrease in CEA was verified in organisms exposed to A. armata exudate in the presence of PA-MPs, when compared to $2 \%$ exudate in the absence of PA-MPs.

\subsection{Byssal Thread Production}

The number of produced byssal threads was not significantly affected in mussels exposed to A. armata exudate $(p>0.05)$. However, a significant decline in the number of byssus was observed in mussels exposed to both PA-MP treatments (with and without the exudate) when compared to control ( $p<0.05$, Figure 5). 

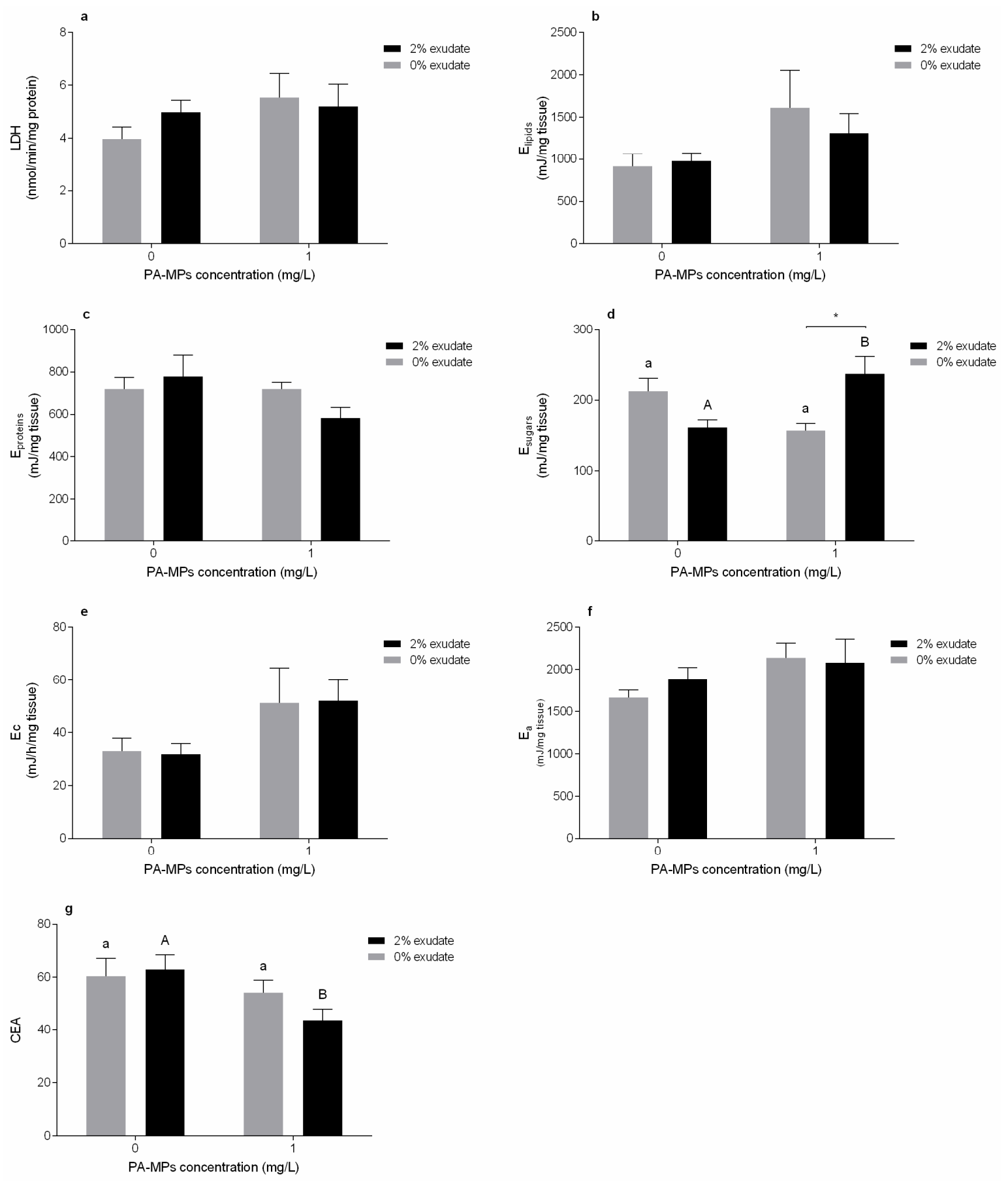

Figure 4. Energy metabolism biomarkers of Mytilus galloprovincialis muscles after $96 \mathrm{~h}$ of exposure to A. armata exudate $(0 \%$ and $2 \%)$ at different polyamide microplastic concentrations $(0$ and $1 \mathrm{mg} / \mathrm{L})$. (a) Lactate dehydrogenase (LDH), (b) lipid contents ( $\left.E_{\text {lipids }}\right)$, (c) protein contents ( $\left.E_{\text {proteins }}\right)$, (d) sugar content $\left(E_{\text {sugars }}\right),(\mathbf{e})$ electron transport system, (f) energy available (Ea), and (g) cellular energy allocation (CEA). All values are presented as mean \pm SEM. * denotes a significant difference between the $0 \%$ and $2 \%$ A. armata exudate in the same PA-MPs concentration. The upper-case letters indicate differences in the $0 \%$ exudate treatments and the different lower-case letters represent differences in the $2 \%$ exudate treatments at the different PA-MPs concentrations. 


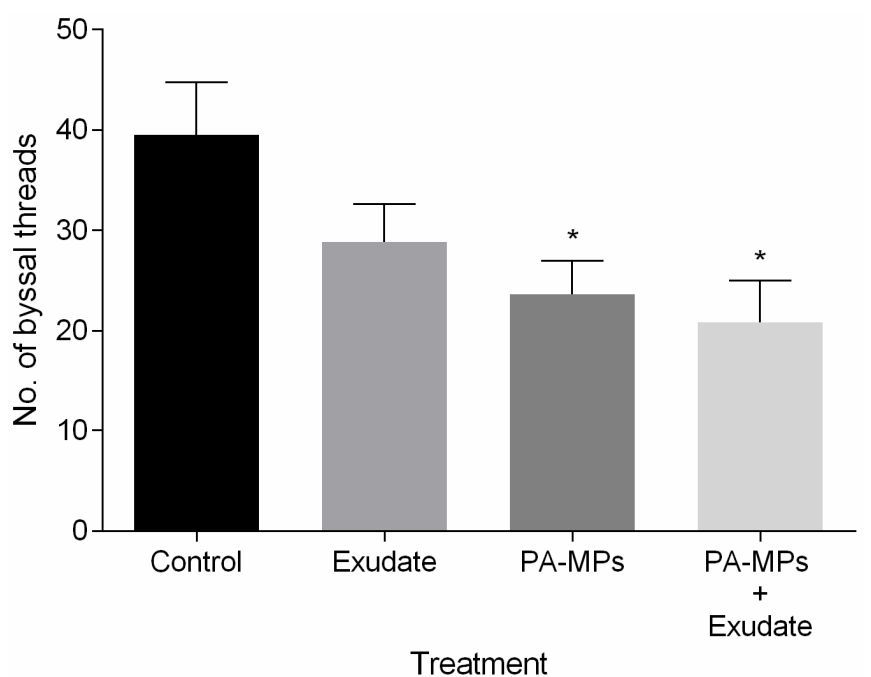

Figure 5. Number of produced byssal threads by Mytilus galloprovincialis during the $96 \mathrm{~h}$ exposure to different treatments: (i) control ( $0 \% ; 0 \mathrm{mg} / \mathrm{L})$; (ii) A. armata exudate (2\%); (iii) PA-MPs (1 mg/L); and (iv) A. armata exudate ( $2 \%$ ) and PA-MPs ( $1 \mathrm{mg} / \mathrm{L})$. All values are presented as mean $\pm \mathrm{SEM}$. * denotes a significant difference compared with the control treatment.

\section{Discussion}

\subsection{Microplastics in the Tissues}

PA-MPs were taken up by M. galloprovincialis, as they are mostly found in the digestive gland, which is in line with previous studies exposing bivalves to treatments containing MPs [13,14,70-72]. A smaller amount of PA-MPs was detected in the gills. Histological analyses also revealed the presence of few particles retained in the gills epithelium of M. galloprovincialis exposed to polystyrene (PS) [73] and to polyethylene (PE) [51], and also of the freshwater bivalve Corbicula fluminea [74].

The highest number of PA-MP particles was found in the digestive gland under the presence of $A$. armata exudate. This may be explained either by the fact that the exudate presence increased the uptake of PA-MP or the exudate compounds could have compromised the mussels' ability to excrete these particles. As A. armata exudate was shown previously to decrease the clearance rate capacity of exposed mussels [45], the second hypothesis seems to be more plausible. The mechanism underlying this process requires further investigation. In contrast, previous studies investigating the MP effects of co-exposure with other contaminants (e.g. benzo(a)pyrene, fluoranthene) in mussels did not find differences in MP accumulation between organisms treated with MPs alone or in combination [51,73].

\subsection{Oxidative Stress and Neurophysiological Biomarkers}

Toxicity of MPs and A. armata exudate is in part mediated by increased reactive oxygen species (ROS) production, which induces antioxidant defences in the exposed organisms to prevent oxidative damage. Such responses are expected following PA-MP exposure, as this polymer may accumulate in the organisms' tissues resulting in physical damage, inflammatory responses $[13,14]$, and the consequent activation of defence mechanisms. In addition, Asparagopsis seaweeds are a source of halogenated compounds that are inextricably linked to ROS production [75]. Catalase (CAT) is at the first line of defence in the elimination of ROS [76], along with other enzymatic defences, such as superoxide dismutase (SOD). GST has an important role in the phase II of biotransformation and non-enzymatic tGSH acts in the neutralization of ROS [77].

In the bivalves, gills have both a respiratory and feeding role and are the first tissue in contact with the stressor [78]. CAT activity in the gills declined in organisms exposed to PA-MPs. $\mathrm{H}_{2} \mathrm{O}_{2}$ is the main precursor of hydroxyl radical in marine organisms [72], and its formation is favoured by ROS production (mainly superoxide anion). CAT may prevent cell damage due to MPs-induced oxidative stress, as this enzyme is involved in 
the removal of $\mathrm{H}_{2} \mathrm{O}_{2}$ by converting the hydrogen peroxide into $\mathrm{H}_{2} \mathrm{O}$ and $\mathrm{O}_{2}$ and acting as a defence mechanism towards exogenous sources of $\mathrm{H}_{2} \mathrm{O}_{2}$ [77]. CAT inhibition was also observed after a 7-day exposure to PS MPs [73]. The authors hypothesised that this enzyme has a biphasic response in the neutralisation of the hydrogen peroxide production, with an activation within the first days of exposure followed by a decrease in activity [73]. Although our study assessed CAT activity after a $96 \mathrm{~h}$ exposure, a similar response may also explain the CAT inhibition after this period. Thus, the depletion of CAT activity observed in the PA-MPs treatment may be related with its involvement in the decomposition of hydrogen peroxide. Reduced CAT activity was also demonstrated by Abidli et al. [48] in M. galloprovincialis females exposed to PE at 100 and $1000 \mu \mathrm{g} / \mathrm{L}$. GST activity was not altered in mussels exposed to any of the treatments. Webb et al. [79] also observed no changes in the GST activity in the mussel Perna canaliculus gills exposed to $0.5 \mathrm{~g}$ PE/L. Furthermore, results suggest a participation of $\mathrm{tGSH}$ as second line of defence following the depletion of CAT activity, with mussels from the combined exposure of A. armata exudate and PA-MPs presenting the lowest tGSH levels. $\mathrm{tGSH}$ is one of the most abundant scavengers in marine organisms that neutralises ROS and acts as a cofactor of various antioxidant enzymes dependent on glutathione [77], and therefore has an important role in the protection against ROS. The decrease in $\mathrm{tGSH}$ levels suggests an active involvement in combating excess reactive oxygen species (ROS) by increasing the consumption of total glutathione to counteract a potential increment of oxidative stress caused by the PA-MPs and the macroalga exuded secondary metabolites. Nevertheless, this decline may also reduce the competence for ROS neutralisation, which increases the oxidative damage potential [80]. In fact, although no lipid peroxidation occurred, oxidative damage at the protein level (PC) was observed in mussels exposed to both stressors combined. The imbalance between the generation of ROS and detoxification could have resulted in this rise in protein carbonyl levels. Protein carbonylation (PC) is a type of protein oxidation that can be promoted by the production of ROS [81]. It usually results in the formation of reactive ketone groups or amino acid aldehydes that can lead to the degradation of protein functions [81]. This may increase PC expression in response to different stressors, such as A. armata exudate and PA-MPs, thus representing a form of oxidative damage. LPO occurs due to a chain of molecular reactions that can culminate in oxidative damage of lipids allowing toxic agents to penetrate cell membranes [76]. In this study, as LPO was not affected in any tissue, it is not expected that changes in the lipid bilayer's structure and function or in membrane permeability occurred. Furthermore, the absence of modifications in LPO suggests the efficiency in activation of ROS scavenging mechanisms to prevent oxidative damage at the lipid level [82].

Oxidative stress-related biomarkers were also assessed in the digestive gland, which is the main surface for PA-MP uptake after being filtered through the gills, as they are also recognised as an important detoxification organ [83]. CAT activity was inhibited in organisms exposed to the combined exposure to PA-MPs and A. armata exudate, and, as in the gills, it is hypothesised that the decrease in this enzymatic antioxidant is due to a strong response in the early stages of exposure leading to its inhibition. Depletion of CAT activity was also observed in the digestive tissue of $M$. galloprovincialis exposed to PE and PS for 7 days [14], Mytilus spp. exposed only to PS also for 7 days [73], and the clam Scrobicularia plana exposed to $1 \mathrm{mg}$ PS/L for 14 days [72]. On the other hand, GST and tGSH were not altered along the different treatments, which may imply that the second phase of the biotransformation of ROS and detoxification was presumably not activated in the mussels' digestive glands, at least at the sampling point used. The absence of significant modifications in GST levels in the digestive tissues of mussels exposed to microplastics was previously demonstrated by Avio et al. [14], as well as the unaltered levels of LPO. Cole et al. [45] also did not find significant lipid peroxidation in the digestive gland of Mytilus spp. exposed to polyamide microfibers. In response to the PA-MP stress factor, which can trigger inflammation processes in the tissues of exposed organisms [84], there 
was oxidative damage in the form of protein carbonylation (PC) in the digestive glands of mussels exposed to the polyamide microplastic treatment.

LPO and PC levels remained unaltered in the muscle tissue in mussels exposed to all the treatments, suggesting that no oxidative damage occurred in this tissue. Although antioxidant defence-related biomarkers were not measured, the absence of effects at the protein and lipid levels allows us to infer that the antioxidant machinery was efficient in the muscle tissue.

$\mathrm{AChE}$ is generally used to evaluate the neurotoxic potential of various compounds in marine organisms [85] and has an important role in the regulation of cholinergic neurotransmissions [86]. Microplastics-induced neurotoxicity has been previously demonstrated in the mussel Mytilus galloprovincialis exposed to $1.5 \mathrm{~g} / \mathrm{L}$ PE and PS $(<100 \mu \mathrm{m})$ [14], the clam Scrobicularia plana exposed to $1 \mathrm{mg}$ PS/L $(20 \mu \mathrm{m})$ [72], and Corbicula fluminea after exposure to $0.2 \mathrm{mg} / \mathrm{L}$ red fluorescent microspheres $(1-5 \mu \mathrm{m})$ [74]. Therefore, if this enzyme is adversely affected, the essential nervous system functions may be disrupted. However, in the present study, no alterations were detected in the AChE activity of either the gills or the digestive gland, which may indicate that the responses in these tissues were not related to neurotoxicity. On the other hand, the AChE activity exhibited an increase in the muscle tissues of mussels exposed to A. armata exudate. Silva et al. [87] discussed that exposure to this seaweed exudate followed by the induction of AChE activity may be related to an induced regulatory overcompensation by increasing $\mathrm{AChE}$ in the organisms ${ }^{\prime}$ cholinergic system. Another possible explanation is when the AChE is released from the cellular membrane surface, which may trigger de novo synthesis to restore this enzyme [88]. Furthermore, this increase in AChE activity may signal an induction of inflammatory reactions, as AChE rise usually occurs in inflamed tissues or cells [89], and may be associated with cell-disrupting processes, especially apoptosis [85]. An AChE activation was previously observed in G. umbilicalis [87] and in the muscle tissue of M. galloprovincialis [45] exposed to lower concentrations of $A$. armata exudate. However, although previous studies have demonstrated neurotransmission impairment attributed to other MPs, in the present study no effect was observed under PA-MP exposure.

\subsection{Energy Metabolism Biomarkers}

LDH enzyme has an important role in the anaerobic pathway of energy production [90] and was not altered in exposed mussels. Thus, there are no indications of energy mobilisation through anaerobic metabolic vias to counteract stress caused by the metabolites released with the A. armata exudate and the presence of PA-MPs.

The energy reserves were measured as lipid, sugar and protein contents, which, in a normal situation, are used in trade-offs between the organisms' basal maintenance and physiological functions. Lipids and proteins were not altered in neither of the treatments. However, there was a significant increase in sugar levels in organisms exposed to the combined treatment of A. armata exudate and PA-MPs. The demand for additional cellular glucose may be related to the induction of gluconeogenesis and may imply a disruption in the energetic metabolism. Lacroix et al. [82] hypothesized that induction of gluconeogenesis could transduce a higher energy storage (in the form of glycogen) in the exposed mussels, but an increased need of glucose to fulfil alternative metabolic routes to combat oxidative stress could also explain this increase. Moreover, the increased gluconeogenesis can be correlated to an increase of reactive oxygen species, as ROS can be generated indirectly by increasing the aerobic metabolism so that organisms are apt to sustain energy costs of metabolic responses to stressful conditions, considering that the electron transport system is a primary site for ROS production [77]. Energy consumption was assessed by determining mitochondrial electron transport system (ETS) activity and may be used to measure the metabolic capacity in response to stress. Mussels exposed to PA-MPs demonstrated increased energy consumption, either with or without the exudate. The increased ETS activity, and consequent increment of aerobic energy production, can be associated with an increase in stress levels while the organisms try to maintain a state 
of physiological homeostasis [91] and may also support the gluconeogenesis hypothesis. Therefore, this metabolic activation demonstrates a transfer of resources to produce energy, allowing the mussels to cope with microplastics-induced stress. Moreover, a potential increment of non-enzymatic antioxidant capacity is suggested by the ETS increase [45] in the presence of PA-MPs. The increase in energy consumption was accompanied by a depletion of CEA activity in mussels exposed to PA-MPs during 4 days, which ultimately represents a significant decrease in the energy budget; this decline being most noticeable when both stressors are combined. CEA suppression implicates a lower amount of energy available for the mussels' growth, reproduction, defence, and byssus production, and thus is more susceptible to additional stress [92]. Shang et al. [93] also demonstrated a CEA decline in Mytilus coruscus exposed during 14 days to high concentrations $\left(10^{4}\right.$ and $10^{6}$ particles/L) of PS microspheres as well as an increased cellular energy demand (ETS activity). On the other hand, Van Cauwenberghe et al. [91] also detected increased ETS activity after exposing $M$. edulis for 14 days to 110 PS microspheres/mL (10, 30 and $90 \mu \mathrm{m})$, but this increased metabolism was not accompanied by any other alterations in the overall energy budget.

\subsection{Byssal Thread Production}

Byssus represent an extracellular and collagenous structure that allows mussels' attachment to the substratum, thus any interference in byssal threads production can diminish the capacity of mussels to firmly anchor to the surface [94], making them prone to dislodgement and more susceptible to natural stressors, such as tides, waves and predation [45]. Production of functional byssus declined in mussels exposed to PA-MPs, either in the presence or absence of the exudate, with a lower number of secreted byssal threads being found under stressor combination. Decreased byssal production was also observed in the mussels Perna viridis [71] and Perna canaliculus [79] exposed to polyvinyl chloride and polyethylene particles, respectively.

The exposure to PA-MPs and combined stressors led mussels to allocate more energy to cope with the oxidative stress, which, together with the high levels of protein oxidation, might have compromised the organisms' ability to invest in the growth and development of structures, such as the byssal threads. Thus, this study suggests that the presence of $A$. armata exudate combined with PA-MPs might increase the vulnerability of $M$. galloprovincialis, as byssal threads are crucial to anchor themselves to the rocky shores and to other mussels. This may consequently impair individuals' fitness, survival, the preservation of mussel beds, and their role in regulating macrofaunal and flora diversity [78].

\section{Conclusions}

In summary, the present findings suggest that $1 \mathrm{mg}$ PA-MP/L in co-exposure with $2 \%$ A. armata exudate present a health hazard to M. galloprovincialis. In particular, the responses of oxidative stress biomarkers and the decrease in the final balance of the energy budget reflected the activation of antioxidant defences in exposed mussels, which prevented lipid peroxidation but not oxidative damage in proteins. Moreover, this was reflected in the impairment of byssus production under exposure to PA-MPs, which can compromise the attachment of mussels to the substratum and mussel bed stability. Thus, a potential amplification of the deleterious effects of the PA-MPs was observed in the presence of this invasive species exudate. This may anticipate that exposure to the secondary metabolites produced by $A$. armata may pose an additional impact to marine biota under the threat of MP pollution.

Supplementary Materials: The following are available online at https:/ / www.mdpi.com/article/10.3 390/toxics10020043/s1, Figure S1: Irregularly shaped polyamide microplastics (PA-MPs). Images taken at $10 \times$ magnification (Zeiss Primo Star light microscope, Jena, Germany), Table S1: Two-way ANOVA analysis results on oxidative stress-related biomarker responses in Mytilus galloprovincialis gills with Asparagopsis armata exudate and PA-MPs exposures as factors, Table S2: Results for two-way ANOVA analysis on biochemical biomarkers responses in the digestive gland of M. galloprovincialis with A. armata 
exudate exposure and water temperature as factors, Table S3: Results for two-way ANOVA analysis on biochemical biomarkers responses in the muscle of $M$. galloprovincialis with $A$. armata exudate exposure and water temperature as factors.

Author Contributions: Conceptualization, D.C., A.L.P.S., and M.D.B.; methodology, H.C.V., D.C., A.C.M.R., A.L.P.S., and M.D.B.; formal analysis, F.G.R., H.C.V., A.C.M.R., and M.D.B.; investigation, F.G.R., H.C.V., S.F.S.P., and M.D.B.; writing-original draft, F.G.R.; writing-review and editing, F.G.R., H.C.V., D.C., S.F.S.P., A.C.M.R., A.L.P.S., A.M.V.M.S., J.M.M.O., and M.D.B.; resources, A.L.P.S., A.M.V.M.S., and M.D.B.; supervision: D.C., A.L.P.S., J.M.M.O., and M.D.B.; project administration: A.L.P.S. and M.D.B.; funding acquisition: A.L.P.S. and M.D.B. All authors have read and agreed to the published version of the manuscript.

Funding: This research was funded through CESAM (UIDP/50017/2020+UIDB/50017/2020+LA/P/ 0094/2020), with financial support from FCT/MCTES through national funds. The authors are thankful for the financial support by the projects INSIDER (PTDC/CTA-AMB/30495/2017) and comPET (PTDC/CTA-AMB/30361/2017) funded by FEDER, through COMPETE2020-Programa Operacional Competitividade e Internacionalização (POCI), and by national funds (OE), through FCT/MCTES. The authors also thank FCT and POPH/FSE (Programa Operacional Potencial Humano/Fundo Social Europeu) for the doctoral grant of H.C.V. (PD/BD/127808/2016). A.L.P.S. is funded by a FCT research contract (CEECIND/01366/2018). M.D.B. is funded by national funds (OE), through FCT, I.P., in the scope of the framework contract foreseen in the numbers 4,5 and 6 of the article 23, of the Decree-Law 57/2016, of 29 August, changed by Law 57/2017, of 19 July.

Institutional Review Board Statement: Not applicable.

Informed Consent Statement: Not applicable.

Data Availability Statement: The data presented in this study is available in the current manuscript, raw data is available on request from the corresponding author.

Conflicts of Interest: The authors declare no conflict of interest.

\section{References}

1. Pinteus, S.; Lemos, M.F.L.; Alves, C.; Neugebauer, A.; Silva, J.; Thomas, O.P.; Botana, L.M.; Gaspar, H.; Pedrosa, R. Marine invasive macroalgae: Turning a real threat into a major opportunity-The biotechnological potential of Sargassum muticum and Asparagopsis armata. Algal Res. 2018, 34, 217-234. [CrossRef]

2. Halpern, B.S.; Walbridge, S.; Selkoe, K.A.; Kappel, C.V.; Micheli, F.; D’Agrosa, C.; Bruno, J.F.; Casey, K.S.; Ebert, C.; Fox, H.E.; et al. A global map of human impact on marine ecosystems. Science 2008, 319, 948-952. [CrossRef]

3. PlasticsEurope. Plastics-the Facts 2020: An analysis of European plastics production, Demand and Waste Data; PlasticsEurope: Brussels, Belgium, 2020.

4. $\quad$ Li, J.; Lusher, A.L.; Rotchell, J.M.; Deudero, S.; Turra, A.; Bråte, I.L.N.; Sun, C.; Shahadat Hossain, M.; Li, Q.; Kolandhasamy, P.; et al. Using mussel as a global bioindicator of coastal microplastic pollution. Environ. Pollut. 2019, 244, 522-533. [CrossRef] [PubMed]

5. Cole, M.; Lindeque, P.; Halsband, C.; Galloway, T.S. Microplastics as contaminants in the marine environment: A review. Mar. Pollut. Bull. 2011, 62, 2588-2597. [CrossRef] [PubMed]

6. Alprol, A.E.; Gaballah, M.S.; Hassaan, M.A. Micro and Nanoplastics analysis: Focus on their classification, sources, and impacts in marine environment. Reg. Stud. Mar. Sci. 2021, 42, 101625. [CrossRef]

7. Beiras, R.; Schönemann, A.M. Currently monitored microplastics pose negligible ecological risk to the global ocean. Sci. Rep. 2020, 10, 22281. [CrossRef] [PubMed]

8. $\quad$ Lindeque, P.K.; Cole, M.; Coppock, R.L.; Lewis, C.N.; Miller, R.Z.; Watts, A.J.R.; Wilson-McNeal, A.; Wright, S.L.; Galloway, T.S Are we underestimating microplastic abundance in the marine environment? A comparison of microplastic capture with nets of different mesh-size. Environ. Pollut. 2020, 265, 114721. [CrossRef]

9. Wright, S.L.; Thompson, R.C.; Galloway, T.S. The physical impacts of microplastics on marine organisms: A review. Environ. Pollut. 2013, 178, 483-492. [CrossRef]

10. Cole, M.; Liddle, C.; Consolandi, G.; Drago, C.; Hird, C.; Lindeque, P.K.; Galloway, T.S. Microplastics, microfibres and nanoplastics cause variable sub-lethal responses in mussels (Mytilus spp.). Mar. Pollut. Bull. 2020, 160, 111552. [CrossRef]

11. Li, J.; Qu, X.; Su, L.; Zhang, W.; Yang, D.; Kolandhasamy, P.; Li, D.; Shi, H. Microplastics in mussels along the coastal waters of China. Environ. Pollut. 2016, 214, 177-184. [CrossRef]

12. Kinjo, A.; Mizukawa, K.; Takada, H.; Inoue, K. Size-dependent elimination of ingested microplastics in the Mediterranean mussel Mytilus galloprovincialis. Mar. Pollut. Bull. 2019, 149, 110512. [CrossRef]

13. Von Moos, N.; Burkhardt-Holm, P.; Köhler, A. Uptake and effects of microplastics on cells and tissue of the blue mussel Mytilus edulis L. after an experimental exposure. Environ. Sci. Technol. 2012, 46, 11327-11335. [CrossRef] [PubMed] 
14. Avio, C.G.; Gorbi, S.; Milan, M.; Benedetti, M.; Fattorini, D.; D’Errico, G.; Pauletto, M.; Bargelloni, L.; Regoli, F. Pollutants bioavailability and toxicological risk from microplastics to marine mussels. Environ. Pollut. 2015, 198, 211-222. [CrossRef] [PubMed]

15. Liu, L.; Xu, K.; Zhang, B.; Ye, Y.; Zhang, Q.; Jiang, W. Cellular internalization and release of polystyrene microplastics and nanoplastics. Sci. Total Environ. 2021, 779, 146523. [CrossRef] [PubMed]

16. Foley, C.J.; Feiner, Z.S.; Malinich, T.D.; Höök, T.O. A meta-analysis of the effects of exposure to microplastics on fish and aquatic invertebrates. Sci. Total Environ. 2018, 631-632, 550-559. [CrossRef]

17. Avio, C.G.; Gorbi, S.; Regoli, F. Plastics and microplastics in the oceans: From emerging pollutants to emerged threat. Mar. Environ. Res. 2017, 128, 2-11. [CrossRef] [PubMed]

18. Zhang, X.; Xia, M.; Zhao, J.; Cao, Z.; Zou, W.; Zhou, Q. Photoaging enhanced the adverse effects of polyamide microplastics on the growth, intestinal health, and lipid absorption in developing zebrafish. Environ. Int. 2022, 158, 106922. [CrossRef]

19. Lusher, A.; Hollman, P.; Mandoza-Hill, J. Microplastics in fisheries and aquaculture: Status of Knowledge on Their Occurrence and Implications for Aquatic Organisms and Food Safety; FAO: Rome, Italy, 2017; Volume 615.

20. Lusher, A.L.; McHugh, M.; Thompson, R.C. Occurrence of microplastics in the gastrointestinal tract of pelagic and demersal fish from the English Channel. Mar. Pollut. Bull. 2013, 67, 94-99. [CrossRef]

21. Thushari, G.G.N.; Senevirathna, J.D.M.; Yakupitiyage, A.; Chavanich, S. Effects of microplastics on sessile invertebrates in the eastern coast of Thailand: An approach to coastal zone conservation. Mar. Pollut. Bull. 2017, 124, 349-355. [CrossRef]

22. Pedrotti, M.L.; Petit, S.; Elineau, A.; Bruzaud, S.; Crebassa, J.C.; Dumontet, B.; Martí, E.; Gorsky, G.; Cózar, A. Changes in the floating plastic pollution of the mediterranean sea in relation to the distance to land. PLoS ONE 2016, 11, e0161581. [CrossRef]

23. Cincinelli, A.; Scopetani, C.; Chelazzi, D.; Martellini, T.; Pogojeva, M.; Slobodnik, J. Microplastics in the Black Sea sediments. Sci. Total Environ. 2021, 760, 143898. [CrossRef]

24. Erni-Cassola, G.; Zadjelovic, V.; Gibson, M.I.; Christie-Oleza, J.A. Distribution of plastic polymer types in the marine environment; A meta-analysis. J. Hazard. Mater. 2019, 369, 691-698. [CrossRef]

25. Davidson, A.D.; Campbell, M.L.; Hewitt, C.L.; Schaffelke, B. Assessing the impacts of nonindigenous marine macroalgae: An update of current knowledge. Bot. Mar. 2015, 58, 55-79. [CrossRef]

26. Thomsen, M.S.; Wernberg, T.; South, P.M.; Schiel, D.R. Non-native Seaweeds Drive Changes in Marine Coastal Communities Around the World. In Seaweed Phylogeography; Hu, Z.M., Fraser, C., Eds.; Springer: Dordrecht, The Netherlands, 2016; pp. 147-185. [CrossRef]

27. Katsanevakis, S.; Wallentinus, I.; Zenetos, A.; Leppäkoski, E.; Çinar, M.E.; Oztürk, B.; Grabowski, M.; Golani, D.; Cardoso, A.C Impacts of invasive alien marine species on ecosystem services and biodiversity: A pan-European review. Aquat. Invasions 2014, 9, 391-423. [CrossRef]

28. Williams, S.L.; Smith, J.E. A global review of the distribution, taxonomy, and impacts of introduced seaweeds. Annu. Rev. Ecol. Evol. Syst. 2007, 38, 327-359. [CrossRef]

29. Molnar, J.L.; Gamboa, R.L.; Revenga, C.; Spalding, M.D. Assessing the global threat of invasive species to marine biodiversity. Front. Ecol. Environ. 2008, 6, 485-492. [CrossRef]

30. Simberloff, D.; Martin, J.L.; Genovesi, P.; Maris, V.; Wardle, D.A.; Aronson, J.; Courchamp, F.; Galil, B.; García-Berthou, E.; Pascal, M.; et al. Impacts of biological invasions: What's what and the way forward. Trends Ecol. Evol. 2013, 28, 58-66. [CrossRef] [PubMed]

31. Bonin, D.R.; Hawkes, M.W. Systematics and life histories of New Zealand Bonnemaisoniaceae (Bonnemaisoniales, Rhodophyta) I. The genus Asparagopsis. N. Z. J. Bot. 1987, 25, 577-590. [CrossRef]

32. Boudouresque, C.F.; Verlaque, M. Biological pollution in the Mediterranean Sea: Invasive versus introduced macrophytes. Mar. Pollut. Bull. 2002, 44, 32-38. [CrossRef]

33. Ní Chualáin, F.; Maggs, C.A.; Saunders, G.W.; Guiry, M.D. The invasive genus Asparagopsis (Bonnemaisoniaceae, Rhodophyta) Molecular systematics, morphology, and ecophysiology of Falkenbergia isolates. J. Phycol. 2004, 40, 1112-1126. [CrossRef]

34. Andreakis, N.; Procaccini, G.; Maggs, C.; Kooistra, W.H.C.F. Phylogeography of the invasive seaweed Asparagopsis (Bonnemaisoniales, Rhodophyta) reveals cryptic diversity. Mol. Ecol. 2007, 16, 2285-2299. [CrossRef]

35. Martins, G.M.; Cacabelos, E.; Faria, J.; Álvaro, N.; Prestes, A.C.L.; Neto, A.I. Patterns of distribution of the invasive alga Asparagopsis armata Harvey: A multi-scaled approach. Aquat. Invasions 2019, 14, 582-593. [CrossRef]

36. Rubal, M.; Costa-Garcia, R.; Besteiro, C.; Sousa-Pinto, I.; Veiga, P. Mollusc diversity associated with the non-indigenous macroalga Asparagopsis armata Harvey, 1855 along the Atlantic coast of the Iberian Peninsula. Mar. Environ. Res. 2018, 136, 1-7. [CrossRef] [PubMed]

37. Maggs, C.A.; Stegenga, H. Red algal exotics on North Sea coasts. Helgol. Meeresunters. 1999, 52, 243-258. [CrossRef]

38. Paul, N.A.; De Nys, R.; Steinberg, P.D. Seaweed-herbivore interactions at a small scale: Direct tests of feeding deterrence by filamentous algae. Mar. Ecol. Prog. Ser. 2006, 323, 1-9. [CrossRef]

39. Sala, E.; Boudouresque, C.F. The role of fishes in the organization of a Mediterranean sublittoral community. I: Algal communities. J. Exp. Mar. Bio. Ecol. 1997, 212, 25-44. [CrossRef]

40. Genovese, G.; Tedone, L.; Hamann, M.T.; Morabito, M. The Mediterranean red alga Asparagopsis: A source of compounds against Leishmania. Mar. Drugs 2009, 7, 361-366. [CrossRef] 
41. Bansemir, A.; Blume, M.; Schröder, S.; Lindequist, U. Screening of cultivated seaweeds for antibacterial activity against fish pathogenic bacteria. Aquaculture 2006, 252, 79-84. [CrossRef]

42. Guerra-García, J.M.; Ros, M.; Izquierdo, D.; Soler-Hurtado, M.M. The invasive Asparagopsis armata versus the native Corallina elongata: Differences in associated peracarid assemblages. J. Exp. Mar. Bio. Ecol. 2012, 416-417, 121-128. [CrossRef]

43. Silva, C.O.; Lemos, M.F.L.; Gaspar, R.; Gonçalves, C.; Neto, J.M.; Silva, C.O. The effects of the invasive seaweed Asparagopsis armata on native rock pool communities: Evidences from experimental exclusion. Ecol. Indic. 2021, 125, 107463. [CrossRef]

44. Silva, C.O.; Novais, S.C.; Soares, A.M.V.M.; Barata, C.; Lemos, M.F.L. Impacts of the Invasive Seaweed Asparagopsis armata Exudate on Energetic Metabolism of Rock Pool Invertebrates. Toxins 2021, 13, 15. [CrossRef] [PubMed]

45. Coelho, S.D.; Vieira, H.C.; Oliveira, J.M.M.; Pires, S.F.S.; Rocha, R.J.M.; Rodrigues, A.C.M.; Soares, A.M.V.M.; Bordalo, M.D. How Does Mytilus galloprovincialis Respond When Exposed to the Gametophyte Phase of the Invasive Red Macroalga Asparagopsis armata Exudate? Water 2021, 13, 460. [CrossRef]

46. Vieira, H.C.; Rodrigues, A.C.M.; Pires, S.F.S.; Oliveira, J.M.M.; Rocha, R.J.M.; Soares, A.M.V.M.; Bordalo, M.D. Ocean warming may enhance biochemical alterations induced by an invasive seaweed exudate in the mussel Mytilus galloprovincialis. Toxics 2021, 9, 121. [CrossRef] [PubMed]

47. Beyer, J.; Green, N.W.; Brooks, S.; Allan, I.J.; Ruus, A.; Gomes, T.; Bråte, I.L.N.; Schøyen, M. Blue mussels (Mytilus edulis spp.) as sentinel organisms in coastal pollution monitoring: A review. Mar. Environ. Res. 2017, 130, 338-365. [CrossRef] [PubMed]

48. Abidli, S.; Pinheiro, M.; Lahbib, Y.; Neuparth, T.; Santos, M.M.; Trigui El Menif, N. Effects of environmentally relevant levels of polyethylene microplastic on Mytilus galloprovincialis (Mollusca: Bivalvia): Filtration rate and oxidative stress. Environ. Sci. Pollut. Res. 2021, 28, 26643-26652. [CrossRef]

49. Arribas, L.P.; Donnarumma, L.; Palomo, M.G.; Scrosati, R.A. Intertidal mussels as ecosystem engineers: Their associated invertebrate biodiversity under contrasting wave exposures. Mar. Biodivers. 2014, 44, 203-211. [CrossRef]

50. Oliveira, J.; Castilho, F.; Cunha, Â.; Pereira, M.J. Bivalve harvesting and production in Portugal: An overview. J. Shellfish Res. 2013, 32, 911-924. [CrossRef]

51. Pittura, L.; Avio, C.G.; Giuliani, M.E.; d’Errico, G.; Keiter, S.H.; Cormier, B.; Gorbi, S.; Regoli, F. Microplastics as vehicles of environmental PAHs to marine organisms: Combined chemical and physical hazards to the mediterranean mussels, Mytilus galloprovincialis. Front. Mar. Sci. 2018, 5, 103. [CrossRef]

52. ASTM Standard E729-96; Standard Guide for Conducting Acute Toxicity Tests on Test Materials with Fishes, Macroinvertebrates, and Amphibians. ASTM International: West Conshohocken, PA, USA, 2014; Voulume 11, 1-22. [CrossRef]

53. Prata, J.C.; Sequeira, I.F.; Monteiro, S.S.; Silva, A.L.P.; da Costa, J.P.; Dias-Pereira, P.; Fernandes, A.J.S.; da Costa, F.M.; Duarte, A.C.; Rocha-Santos, T. Preparation of biological samples for microplastic identification by Nile Red. Sci. Total Environ. 2021, 783, 147065. [CrossRef]

54. Campbell, S.H.; Williamson, P.R.; Hall, B.D. Microplastics in the gastrointestinal tracts of fish and the water from an urban prairie creek. Facets 2017, 2, 395-409. [CrossRef]

55. Bradford, M.M. A rapid and sensitive method for the quantitation of microgram quantities of protein utilizing the principle of protein-dye binding. Anal. Biochem. 1976, 72, 248-254. [CrossRef]

56. Ellman, G.L.; Courtney, K.D.; Andres, V.; Featherstone, R.M. A new and rapid colorimetric determination of acetylcholinesterase activity. Biochem. Pharmacol 1961, 7, 88-95. [CrossRef]

57. Domingues, I.; Gravato, C. Oxidative stress assessment in zebrafish larvae. Methods Mol. Biol. 2018, 1797, 477-486. [CrossRef] [PubMed]

58. Claiborne, A. Catalase activity. In CRC Handbook of Methods in Oxygen Radical Research; Greenwald, R.A., Ed.; CRC Press: Boca Raton, FL, USA, 1985; pp. 283-284.

59. Habig, W.H.; Pabst, M.J.; Jakoby, W.B. Glutathione S transferases. The first enzymatic step in mercapturic acid formation. J. Biol. Chem. 1974, 249, 7130-7139. [CrossRef]

60. Baker, M.A.; Cerniglia, G.J.; Zaman, A. Microtiter plate assay for the measurement of glutathione and glutathione disulfide in large numbers of biological samples. Anal. Biochem. 1990, 190, 360-365. [CrossRef]

61. Tietze, F. Enzymic method for quantitative determination of nanogram amounts of total and oxidized glutathione: Applications to mammalian blood and other tissues. Anal. Biochem. 1969, 27, 502-522. [CrossRef]

62. Rodrigues, A.C.M.; Gravato, C.; Quintaneiro, C.; Bordalo, M.D.; Barata, C.; Soares, A.M.V.M.; Pestana, J.L.T. Energetic costs and biochemical biomarkers associated with esfenvalerate exposure in Sericostoma vittatum. Chemosphere 2017, 189, 445-453. [CrossRef]

63. Bird, R.P.; Draper, H.H. Comparative Studies on Different Methods of Malonaldehyde Determination. Methods Enzym. 1984, 105, 299-305. [CrossRef]

64. Mesquita, C.S.; Oliveira, R.; Bento, F.; Geraldo, D.; Rodrigues, J.V.; Marcos, J.C. Simplified 2,4-dinitrophenylhydrazine spectrophotometric assay for quantification of carbonyls in oxidized proteins. Anal. Biochem. 2014, 458, 69-71. [CrossRef]

65. Vassault, A. Lactate dehydrogenase. In Methods of Enzymatic Analysis-Enzymes: Oxireductases, Transferase; Bergmyer, M.O., Ed.; Academic Press: New York, NY, USA, 1983; pp. 118-126.

66. Diamantino, T.C.; Almeida, E.; Soares, A.M.V.M.; Guilhermino, L. Lactate dehydrogenase activity as an effect criterion in toxicity tests with Daphnia magna straus. Chemosphere 2001, 45, 553-560. [CrossRef] 
67. De Coen, W.; Janssen, C.R. The use of biomarkers in Daphnia magna toxicity testing. IV.Cellular Energy Allocation: A new methodology to assess the energy budget of toxicant-stressed Daphnia populations. J. Aquat. Ecosyst. Stress Recover 1997, 6, 43-45. [CrossRef]

68. Rodrigues, A.C.M.; Gravato, C.; Quintaneiro, C.; Golovko, O.; Žlábek, V.; Barata, C.; Soares, A.M.V.M.; Pestana, J.L.T. Life history and biochemical effects of chlorantraniliprole on Chironomus riparius. Sci. Total Environ. 2015, 508, 506-513. [CrossRef]

69. Gnaiger, E. Calculation of Energetic and Biochemical Equivalents of Respiratory Oxygen Consumption. In Polarographic Oxygen Sensors; Springer: Berlin/Heidelberg, Germany, 1983; pp. 337-375.

70. Browne, M.A.; Dissanayake, A.; Galloway, T.S.; Lowe, D.M.; Thompson, R.C. Ingested microscopic plastic translocates to the circulatory system of the mussel, Mytilus edulis (L.). Environ. Sci. Technol. 2008, 42, 5026-5031. [CrossRef]

71. Rist, S.E.; Assidqi, K.; Zamani, N.P.; Appel, D.; Perschke, M.; Huhn, M.; Lenz, M. Suspended micro-sized PVC particles impair the performance and decrease survival in the Asian green mussel Perna viridis. Mar. Pollut. Bull. 2016, 111, 213-220. [CrossRef]

72. Ribeiro, F.; Garcia, A.R.; Pereira, B.P.; Fonseca, M.; Mestre, N.C.; Fonseca, T.G.; Ilharco, L.M.; Bebianno, M.J. Microplastics effects in Scrobicularia plana. Mar. Pollut. Bull. 2017, 122, 379-391. [CrossRef] [PubMed]

73. Paul-Pont, I.; Lacroix, C.; González Fernández, C.; Hégaret, H.; Lambert, C.; Le Goïc, N.; Frère, L.; Cassone, A.L.; Sussarellu, R.; Fabioux, C.; et al. Exposure of marine mussels Mytilus spp. to polystyrene microplastics: Toxicity and influence on fluoranthene bioaccumulation. Environ. Pollut. 2016, 216, 724-737. [CrossRef] [PubMed]

74. Guilhermino, L.; Vieira, L.R.; Ribeiro, D.; Tavares, A.S.; Cardoso, V.; Alves, A.; Almeida, J.M. Uptake and effects of the antimicrobial florfenicol, microplastics and their mixtures on freshwater exotic invasive bivalve Corbicula fluminea. Sci. Total Environ. 2018, 622-623, 1131-1142. [CrossRef] [PubMed]

75. Thapa, H.R.; Lin, Z.; Yi, D.; Smith, J.E.; Schmidt, E.W.; Agarwal, V. Genetic and Biochemical Reconstitution of Bromoform Biosynthesis in Asparagopsis Lends Insights into Seaweed Reactive Oxygen Species Enzymology. ACS Chem. Biol. 2020, 15, 1662-1670. [CrossRef]

76. Prokić, M.D.; Radovanović, T.B.; Gavrić, J.P.; Faggio, C. Ecotoxicological effects of microplastics: Examination of biomarkers, current state and future perspectives. TrAC-Trends Anal. Chem. 2019, 111, 37-46. [CrossRef]

77. Regoli, F.; Giuliani, M.E. Oxidative pathways of chemical toxicity and oxidative stress biomarkers in marine organisms. Mar. Environ. Res. 2014, 93, 106-117. [CrossRef] [PubMed]

78. Gosling, E. Marine Bivalve Molluscs, 2nd ed.; John Wiley \& Sons: Hoboken, NJ, USA, 2015.

79. Webb, S.; Gaw, S.; Marsden, I.D.; McRae, N.K. Biomarker responses in New Zealand green-lipped mussels Perna canaliculus exposed to microplastics and triclosan. Ecotoxicol. Environ. Saf. 2020, 201, 110871. [CrossRef]

80. Magara, G.; Elia, A.C.; Syberg, K.; Khan, F.R. Single contaminant and combined exposures of polyethylene microplastics and fluoranthene: Accumulation and oxidative stress response in the blue mussel, Mytilus edulis. J. Toxicol. Environ. Health-Part A Curr. Issues 2018, 81, 761-773. [CrossRef] [PubMed]

81. Suzuki, Y.J.; Carini, M.; Butterfield, D.A. Protein carbonylation. Antioxid. Redox Signal. 2010, 12, 323-325. [CrossRef]

82. Lacroix, C.; Richard, G.; Seguineau, C.; Guyomarch, J.; Moraga, D.; Auffret, M. Active and passive biomonitoring suggest metabolic adaptation in blue mussels (Mytilus spp.) chronically exposed to a moderate contamination in Brest harbor (France). Aquat. Toxicol. 2015, 162, 126-137. [CrossRef] [PubMed]

83. Dobal, V.; Suárez, P.; Ruiz, Y.; García-Martín, O.; Juan, F.S. Activity of antioxidant enzymes in Mytilus galloprovincialis exposed to tar: Integrated response of different organs as pollution biomarker in aquaculture areas. Aquaculture 2022, 548, 737638. [CrossRef]

84. Silva, C.J.M.; Patrício Silva, A.L.; Campos, D.; Machado, A.L.; Pestana, J.L.T.; Gravato, C. Oxidative damage and decreased aerobic energy production due to ingestion of polyethylene microplastics by Chironomus riparius (Diptera) larvae. J. Hazard. Mater. 2021, 402, 123775. [CrossRef]

85. Zhang, X.J.; Yang, L.; Zhao, Q.; Caen, J.P.; He, H.Y.; Jin, Q.H.; Guo, L.H.; Alemany, M.; Zhang, L.Y.; Shi, Y.F. Induction of acetylcholinesterase expression during apoptosis in various cell types. Cell Death Differ. 2002, 9, 790-800. [CrossRef]

86. Fonte, E.; Ferreira, P.; Guilhermino, L. Temperature rise and microplastics interact with the toxicity of the antibiotic cefalexin to juveniles of the common goby (Pomatoschistus microps): Post-exposure predatory behaviour, acetylcholinesterase activity and lipid peroxidation. Aquat. Toxicol. 2016, 180, 173-185. [CrossRef]

87. Silva, C.O.; Simões, T.; Félix, R.; Soares, A.M.V.M.; Barata, C.; Novais, S.C.; Lemos, M.F.L. Asparagopsis armata Exudate Cocktail: The Quest for the Mechanisms of Toxic Action of an Invasive Seaweed on Marine Invertebrates. Biology 2021, 10, 223. [CrossRef]

88. Espinoza, B.; Silman, I.; Arnon, R.; Tarrab-Hazdai, R. Phosphatidylinositol-specific phospholipase C induces biosynthesis of acetylcholinesterase via diacylglycerol in Schistosoma mansoni. Eur. J. Biochem. 1991, 195, 863-870. [CrossRef]

89. Gambardella, C.; Morgana, S.; Ferrando, S.; Bramini, M.; Piazza, V.; Costa, E.; Garaventa, F.; Faimali, M. Effects of polystyrene microbeads in marine planktonic crustaceans. Ecotoxicol. Environ. Saf. 2017, 145, 250-257. [CrossRef] [PubMed]

90. Shahriari, A.; Dawson, N.J.; Bell, R.A.V.; Storey, K.B. Stable suppression of lactate dehydrogenase activity during anoxia in the foot muscle of Littorina littorea and the potential role of acetylation as a novel posttranslational regulatory mechanism. Enzyme Res. 2013, 2013, 461374. [CrossRef] 
91. Van Cauwenberghe, L.; Claessens, M.; Vandegehuchte, M.B.; Janssen, C.R. Microplastics are taken up by mussels (Mytilus edulis) and lugworms (Arenicola marina) living in natural habitats. Environ. Pollut. 2015, 199, 10-17. [CrossRef]

92. Erk, M.; Ivanković, D.; Strižak, Ž. Cellular energy allocation in mussels (Mytilus galloprovincialis) from the stratified estuary as a physiological biomarker. Mar. Pollut. Bull. 2011, 62, 1124-1129. [CrossRef] [PubMed]

93. Shang, Y.; Wang, X.; Chang, X.; Sokolova, I.M.; Wei, S.; Liu, W.; Fang, J.K.H.; Hu, M.; Huang, W.; Wang, Y. The Effect of Microplastics on the Bioenergetics of the Mussel Mytilus coruscus Assessed by Cellular Energy Allocation Approach. Front. Mar. Sci. 2021, 8, 1-8. [CrossRef]

94. Bell, E.C.; Gosline, J.M. Mechanical design of mussel byssus: Material yield enhances attachment strength. J. Exp. Biol. 1996, 199, 1005-1017. [CrossRef] 